\title{
People v. Shirokow: Abolishing Prescriptive Water Rights Against the State
}

For the past sixty-five years it has been an open question in California whether a nonriparian ${ }^{1}$ water user could acquire a prescriptive water right without a permit. ${ }^{2}$ In People v. Shirokow, ${ }^{3}$ the California Supreme Court resolved part of the question by holding that one who uses waters subject to statutory appropriation without prior authorization from the State Water Resources Control Board ${ }^{4}$ can never acquire a prescriptive water right against the state. The court also held that the state, pursuant to Water Code section $1052,{ }^{5}$ may enjoin any unauthorized use of these public waters.

Part I of this Note outlines the facts of the case. Part II briefly describes the doctrinal and political sources of California's water rights system, providing the background for Part III's description of the court's reasoning. Part IV analyzes the decision in the context of California's constitutional water conservation policy. ${ }^{6}$ It argues that while the result in Shirokow was correct, constitutional policy requires that proof of waste be recognized as an affirmative defense in a section 1052 injunction proceeding. Fimally, Part $\mathrm{V}$ assesses the impact of the decision on the prescriptive water rights doctrine. It concludes that recognizing limited prescriptive rights against private parties is consistent with state water policy.

1. A riparian derives his water right from owning land immediately adjacent to a stream. For a further discussion of riparian rights, see text accompanying notes 39-54 infra.

2. This question has existed since the passage of the 1913 Water Commission Act, 1913 Cal. Stats., ch. 586, $\S \S 1-46$ at 1012-33 (present version codified in scattered sections of CAL. WATER CODE (Deering 1977)).

3. 26 Cal. 3d 301, 605 P.2d 859, 162 Cal. Rptr. 30 (1980) (Mosk, J.) (5-2 decision).

4. The Water Resources Control Board is authorized by CAL. WATER CODE $\S 174$ (Deering 1977). Hereinafter the Water Resources Control Board is referred to as the Board.

5. CAL. WATER CODE $\S 1052$ (Deering 1977) provides:

The diversion or use of water subject to the provisions of this division other than as authorized in this division is a trespass, and the board may institute in the superior court in and for any county wherein such diversion or use is attempted appropriate action to have such trespass enjoined.

All statutory references in this Note are to the Water Code unless otherwise noted.

6. The term "conservation" in the California Constitution means that the state's water resources are to be put to reasonable and beneficial use "to the fullest extent of which they are capable." CAL. Const. art. X, $\$ 2$, quoted in full at note 52 infra. 


\section{The FaCts of The CAse}

In 1965, defendant Shirokow acquired approximately four thousand acres of land in the low inountain region of eastern Madera County for cattle grazing and recreation. The land is located about one mile south of the headwaters of Arnold Creek, an intermittent stream that flows across Shirokow's property during the rainy wimter and spring months but is dry the remainder of the year. ${ }^{7}$

Before 1960, Shirokow's predecessor in interest built a diversion dain and reservoir on Arnold Creek to store water for livestock watering $^{8}$ and fishing. The dain captures all of Arnold Creek's flow until the reservoir is filled. Then, except for evaporation, seepage and livestock water, all water passes over a spillway and continues down the creek, eventually reaching the San Joaquin River above Friant Dam, a part of the Central Valley Project which is under federal jurisdiction. ${ }^{9}$ Except in drought years, the reservoir can store sufficient water for an entire year.

Shirokow twice applied for but never obtained a perinit to appropriate the impounded water as required by the Water Code. ${ }^{10}$ The Board demed the first apphication when Shirokow failed to coinply with a brush removal requireinent. Shirokow abandoned the second apphication upon learning that reinoving the brush would cost $\$ 8,500 .{ }^{11}$

In 1976, the State Attorney General's office, at the request of the Board, filed a complaint pursuant to section $1052^{12}$ to enjoin the unauthorized water storage. Shirokow admitted that the dam had been built

7. 26 Cal. 3d at 305,605 P.2d at 862,162 Cal. Rptr. at 33.

8. Stock watering is an approved riparian water use. Rancho Santa Margarita v. Vail, 11 Cal. 2d 501, 561, 81 P.2d 533, 563 (1938); Cowell v. Armstrong, 210 Cal. 218, 226, 290 P. 1036, 1039 (1930). Thus, as a riparian owner, Shirokow could have used Arnold Creek for stock watering without a permit. See text accompanying notes 39-47 infra. He could not store the water, however, because seasonal storage is not a proper riparian use. Moore v. Cahfornia Or. Power Co., 22 Cal. 2d 725, 731, 734, 140 P.2d 798, 803-04 (1943).

9. The Central Valley Project is not part of the state water system. California proposed building the Central Valley Project in 1933 to harness and redistribute the waters of the Sacramento and San Joaquin rivers. When the depression made it impossible for the state to sell the bonds necessary to finance the project, the federal government, at the state's request, took over the project. See 1 H. Rogers \& A. Nichols, Water For Californla $\$ \$ 26-28$ (1967) [hereinafter cited as Rogers \& Nichols].

10. See text accompanying notes 31-38 infra.

11. 26 Cal. 3d at 305 n.4, 310, 605 P.2d at 863 n.4, 866, 162 Cal. Rptr. at 33 n.4, 36. CAL. WATER CODE $\$ 1253$ (Deering 1977) (see text accompanying note 38 infra) pernits the Board to inpose conditions upon a permittee. Indeed, Cal. Water Code $\S 1393$ (Deering 1977) requires that the Board include a brnsh removal requirement in any permit for the construction of a reservoir with a capacity of 50 acre-feet or more. Shirokow's reservoir had a capacity of only 19.5 acrefeet. 26 Cal. 3d at 305, 605 P.2d at 862, 162 Cal. Rptr. at 33.

12. See note 5 supra. 
and used without a permit but alleged that he and his predecessors had acquired a prescriptive right ${ }^{13}$ by impounding the water openly, notoriously, and under claim of right since before $1960 .{ }^{14}$ The state conceded that Shirokow's use of the water was reasonable and beneficial ${ }^{15}$ and that Shirokow and his predecessors in interest had paid all taxes assessed on the water. ${ }^{16}$ On these facts, the trial court held that Shirokow had perfected a prescriptive right and denied the state's request for injunctive relief. The Fifth District Court of Appeal affirmed, holding that the prescriptive taking of water is outside the regulatory scheme of the Water Code and that Shirokow had perfected a prescriptive water right by taking the water in derogation of the rights of downstreain riparian owners and prior appropriators. ${ }^{17}$

The Cahfornia Supreme Court reversed, unanimously holding that Shirokow had not perfected a prescriptive water right. ${ }^{18}$ The court split, however, as to whether the Board was entitled to enjoin the unauthorized diversion under section 1052. The majority held that Shirokow had no right to inpound water without complying with the Water Code's appropriation procedures and that a section 1052 injunction was proper. ${ }^{19}$ The dissent argued that as a prerequisite to an injunction, the Board should be required to show that the water would not be wasted if an injunction issued. ${ }^{20}$

13. A water right is not a possessory right to the corpus of water. One who has a water right has a usufructory right-a right to the use only. Rancho Santa Margarita v. Vail, 11 Cal. 2d 501, 555, 81 P.2d 533, 560 (1938) (riparian rights are usufructory); CAL. WATER CODE $§ 1001$ (Deering 1977) (appropriative rights are usufructory).

14. 26 Cal. 3d at 305-06, 605 P.2d at 863, 162 Cal. Rptr. at 33 .

15. Id. at 313,605 P.2d at 868,162 Cal. Rptr. at 38 (Clark, J., concurring and dissenting).

16. Id. at 305,605 P. $2 \mathrm{~d}$ at 863,162 Cal. Rptr. at 33 .

17. People v. Shirokow, 153 Cal. Rptr. 141, 151-52 (5th Dist. 1979). Under California law, court of appeal opinions are depublished upon grant of hearing by the California Supreme Court. Thus, there can be no citation to this opinion before the California courts. CAL. R. CT. 977.

18. 26 Cal. $3 \mathrm{~d}$ at 313, 605 P.2d at 867,162 Cal. Rptr. at 38 (Clark, J., concurring and dissenting).

19. Id. at $309-10,605$ P.2d at 865,162 Cal. Rptr. at 36 .

20. Id. at 316,605 P.2d at 869,162 Cal. Rptr. at 40 (Clark, J., concurring and dissenting).

The court also held that Shirokow did not have a statutory water right under CAL. WATER CODE $\$ \S 1226-4$, (Deering 1977), adopted in 1974 to protect stockpond owners. $26 \mathrm{Cal}$. 3d at 313, 605 P.2d at 868, 162 Cal. Rptr. at 38. These sections declare that "' $t$ the owner of any [stockpond] constructed prior to January 1, 1969, the capacity of which is not in excess of 10 acre-feet on January $1,1975, \ldots$ is declared to have a valid water right with a priority as of the date of construction of the dam." CAL. WATER CODE $§ 1226.1$ (Deering 1977). Because Shirokow's reservoir had a capacity of 19.5 acre-feet, $26 \mathrm{Cal}$. 3d at $305,605 \mathrm{P} .2 \mathrm{~d}$ at $862,162 \mathrm{Cal}$. Rptr. at 33 , he did not satisfy the requirement that the stockpond must have a "capacity . . not in excess of 10 acre-feet." CAL. WATER CODE $\$ 1226.1$ (Deering 1977) (emphasis added). The dissent erroneously argued Shirokow should have been entitled to impound up to 10 acre-feet. $26 \mathrm{Cal}$. $3 \mathrm{~d}$ at 318, 605 P.2d at 871, 162 Cal. Rptr. at 41 (Clark, J., concurring and dissenting). The court's holding is consistent with the Board's interpretation that "the application-permit-license procedure . . . is still the only legal way to obtain a water right for stockponds . . . which are larger 
II.

\section{California's Water Rights System}

A right to use water in California may be obtained by complying with statutory appropriation procedures or by acquiring title to land adjoining a stream. ${ }^{21}$ Controversy exists as to whether water rights may also be acquired by adverse possession. ${ }^{22}$ This section discusses the development of the appropriative, riparian, and prescriptive doctrines before Shirokow. It also identifies another imfluence on Shirokow - the policy problems addressed in 1978 by the Governor's Commission to Review California Water Riglits Law. ${ }^{23}$

\section{A. The Appropriative Water Rights Doctrine}

The system of water rights now known as the appropriation doctrine was developed by California gold mmers and approved in $\mathbf{1 8 5 5}$ by the California Supreme Court. ${ }^{24}$ Since the ininers were only trespassers on government land, they could not rely on the traditional common law water rights accorded to landowners. ${ }^{25}$ Taking a practical approach, the mimers agreed among themselves that water rights could be acquired simply by diverting water from where it was available to where it was needed-often to land some distance from the stream. ${ }^{26}$ The "first in time, first in right" standard governed priorities. ${ }^{27}$ These two principles are still fundamental to the modern appropriation doctrine. ${ }^{28}$

In 1872, the California legislature provided that water rights could be appropriated by posting notice at the place of intended diversion

than 10 acre-feet." Regulations and Information Pertaining to Appropriation of WATER IN CALIFORNIA 73 (1977) [hereinafter cited as APPROPRIATION OF WATER].

21. California was the first state to adopt this dual system of water rights. Consequently, the system is often called the California doctrine. See W. Hutchins, The California Law of WATER RIGHTS 40 (1956) [hereinafter cited as Hutchins].

A third kind of water right, a pueblo right, applies only to the use of water withm the city limits of a city that succeeded a Spanish or Mexican pueblo. A pueblo right gives the city a paramount right to the water of a stream whicl fiowed through the original pueblo. See HUTCHINS at 256.

22. See text accompanying notes 55-77 infra.

23. Governor's Commission to Review California Water Rights Law, Final RePORT (1978) [heremafter cited as GOVERNOR's COMMISSION].

24. Irwin v. Phillips, 5 Cal. 140 (1855).

25. See 3 B. Witkin, Summary of California Law $\S 577$, at 2243 (8th ed. 1973) [hereinafter cited as WITKIN].

26. Irwin v. Phillips, 5 Cal. at 146. See HutchINS, supra note 21 , at 41.

27. 5 Cal. at 147 .

28. See APPROPRIATION of WATER, supra note 20, at 3 (1977) ("anyone who intends to divert water . . . to use on land which is not riparian to the source . . . should apply for a permit from the board"); CAL. WATER CODE $§ 1455$ (Deering 1977) (permit gives priority of right as of the date of the application). 
and filing a copy of the notice with the county recorder. ${ }^{29}$ Between 1872 and 1914, appropriators could use either this statutory method or the judicially approved common law method. ${ }^{30}$ Both were superseded in 1914 by the permit and licensing system that now governs appropriation of surface waters and subterranean streams. ${ }^{31}$

Under the perinit system, anyone who needs water may apply for an appropriation permit; land ownership is not required..$^{32}$ If unappropriated water ${ }^{33}$ is available and the Board believes it is in the public interest to approve the application, ${ }^{34}$ the Board grants a permit to appropriate a specific amount of water ${ }^{35}$ The water must be used for a reasonable and beneficial purpose. ${ }^{36}$ If it is not used for three years, the use right reverts to the state..$^{37}$ In granting a permit, the Board may impose "such terms and conditions as in its judgment will best develop, conserve and utilize in the public interest the water sought to be appropriated."38

\section{B. The Riparian Doctrine}

Under the riparian doctrine, rights to water are considered part and parcel of title to the land adjoining or "riparian" to the watercourse. ${ }^{39}$ The origmal grant determines the extent of land which is riparian. ${ }^{40}$ Thus, a large tract with small frontage on a stream may all be

29. CAL. Civ. CoDE $\$ \S 1410-1422$ (West 1954). Many of the sections relating to the appropriation doctrine (CAL. CIV. CODE $\$ \S 1410-1422$ (West 1954)) have been repealed and the remaining sections seem to be obsolete, since one may no longer acquire an appropriative right by posting notice of an intention to divert. CAL. WATER CODE $\$ 1225$ (Deering 1977).

30. Under the posting and recording system, if water was diverted and used within a reasonable time, priority related back to the date of posting. CAL. CIv. CODE $\S 1418$ (West 1954). Under the common law method, priority did not attach until the water was beneficially used. Utt v. Frey, 106 Cal. 392, 396, 39 P. 807, 808 (1895).

31. Water Commission Act, 1913 Cal. Stats., ch. 586, $\$ \S 1-46$, at 1012-33 (current version at CAL. WATER CODE $§ \S 100-1801$ (Deering 1977)).

The permit system was made the exclusive method for acquiring an appropriative right in 1923. 1923 Cal. Stats., ch. $87, \S 1$, at 162 (current version at CAL. WATER CODE $\$ 1225$ ).

The Water Code's appropriation provisions do not apply to percolating ground water. See id. at $\$ 1200$.

32. See Cal. Water Code $\S 1252 ; 1$ Rogers \& Nichols, supra note $9, \S \S 195-196$.

33. For a definition of unappropriated water, see CAL. WATER CODE $\S 1202$.

34. Id. $\S 1255$.

35. Id. $\S \S 1380,1381$.

36. Id. $\$ 1240$.

37. Id. $\S 1241$. Exceptions to the forfeiture rule are made for nonuse of appropriative rights on Indian trust lands, for nonuse by reason of complianee with crop control or soil conservation contracts and other cases of hardship, and for nonuse because of water conservation efforts. Id. $\S \S 1011,1241.5,1241.6$.

38. Id. $\S 1253$.

39. Lux v. Haggin, 69 Cal. 255, 10 P. 674 (1886); Hutchins, supra note 21, at 187, 189.

40. Rancho Santa Margarita v. Vail, 11 Cal. 2d 501, 528, 81 P.2d 533, 547 (1938). 
riparian so long as it is all within the watershed. ${ }^{41}$ In contrast, if the original owner secured a patent from the government to a narrow strip along the watercourse, that land alone would have riparian rights. ${ }^{42}$ Contiguous parcels, even if they eventually becaine the property of the riparian, would never have riparian rights. ${ }^{43}$

Unlike appropriators, riparians have no fixed right to a specific quantity of water, and no priorities exist ainong riparian landowners on a watercourse. ${ }^{44}$ Rather, the right inust be shared proportionately annong the riparian landowners no inatter who uses the water first. ${ }^{45}$ The riparian may not divert water to lands not riparian to the streain. ${ }^{46}$ Nor inay he store more water than he needs in a wet season for later use in a dry one, even though the water is eventually used on riparian lands. ${ }^{47}$

Since 1866, when the California Supreme Court held that riparian rights coexist im California with appropriative rights, ${ }^{48}$ courts have generally held that riparian rights supersede conflicting appropriative claims. ${ }^{49}$ Until 1928, riparians were entitled, as against appropriators, to insist on the full, undiminished flow of the stream past their land, whether or not the riparian actually used the water. ${ }^{50}$ Consequently, any diversion of water for nonriparian use was a trespass against the rightful owner-the riparian. ${ }^{51}$ In 1928, however, voters approved an

41. Id. See 1 Rogers \& N1CHols, supra note $9, \S 163$.

42. HutchlNs, supra note 21 , at 200-01.

43. See Hudson v. West, 47 Cal. 2d 823, 830, 306 P.2d 807, 810 (1957); Boehmer v. Big Rock Irrigation District, 117 Cal. 19, 26, 48 P. 908, 910 (1897).

44. Half Moon Bay Land Co. v. Cowell, 173 Cal. 543, 549, 160 P. 675, 678 (1916); see HutCHINS, supra note 21 , at $40-41$.

45. GOVERNOR's COMMISSION, supra note 23, at 6.

46. 2 W. Hutchins, Water Rights Laws in the Nineteen Western States 134-35 (completed by H. Ellis \& J. DeBraat, 1974) [heremafter cited as HutchiNs-1974].

47. Moore v. California Or. Power Co., 22 Cal. 2d 725, 731, 734, 140 P.2d 798, 803-04 (1943); Colorado Power Co. v. Pacific Gas \& Elec. Co., 218 Cal. 559, 564-65, 24 P.2d 495, 497-98 (1933). See Meridian, Ltd. v. City \& County of San Francisco, 13 Cal.2d 424, 450, 90 P.2d 537, 549 (1939) (right of storage can only be exercised pursuant to appropriation lawfully made). This principle would apply to Shirokow's water storage. See note 8 and accompanying text supra.

48. Lux v. Haggim, $69 \mathrm{Cal}$. 255, 10 P. 674 (1886). In $L u x$ the court reasoned that the legislature accepted the English common law system of riparian rights when it adopted English common law, see CAL. Civ. CoDE $\S 22.2$ (West 1954), and because the legislature did not abrogate this common law system when it adopted the statutory appropriation doctrine, riparian rights must coexist in Cahfornia with appropriative rights. 69 Cal. at 368-70, 376, 379-82, 10 P. at 739, 744, $746-48$.

49. HuTCHINS, supra note 21, at 62-63. An appropriator would prevail over an upper riparian owner, however, if the lower appropriation is on government land and is made before the upper riparian government land is patented. San Joaqum \& Kings River Canal \& Irr. Co. v. Worswick, 187 Cal. 674, 685, 203 P. 999, 1004 (1922).

50. Herminghaus v. Southern Cal. Edison Co., 200 Cal. 81, 112, 252 P. 607, 619-20 (1926), cert. dismissed, 275 U.S. 486 (1927).

51. See D. Anderson, Governor's Comm'n to Review California Water Rights Law, Staff Paper No. 4, Riparian Water Rights In CaLiForn1a at 84-85 (1977). 
amendment to the California Constitution restricting the riparian right to waters that can be put to reasonable and beneficial use. ${ }^{52} \mathrm{~A}$ riparian can no longer enjom an appropriator from using water that the riparian does not need. 53 This "surplus water" is considered public water, belonging to the state, and is subject to appropriation by the Board under the Water Code. ${ }^{54}$

\section{The Prescriptive Rights Doctrine}

Historically, California courts have also permitted a water user to perfect a water right under the prescriptive rights doctrine. ${ }^{55}$ Under this doctrine, if water is diverted and used in derogation of the rights of the person lawfully entitled to the water and if certain doctrinal requirements are satisfied, the adverse use may ripen into a prescriptive right. ${ }^{56}$ This right bars the rightful owner from objecting to the diversion and thereby vests the adverse user with an absolute, unassailable water right. ${ }^{57}$

The doctrinal requirements are analogous to those necessary to perfect prescriptive title to real property. The use must be open, contimuous and uninterrupted, under claim of exclusive right, for a period of five years. ${ }^{58}$ The taking must be adverse and hostile to the rights of

52. CAL. Const. art. XIV, $\S 3$ (current version at art. X, $\S 2$ ). The full text reads as follows: It is hereby declared that because of the conditions prevailing in this State the general welfare requires that the water resources of the State be put to beneficial use to the fullest extent of which they are capable, and that the waste or unreasonable use or unreasonable method of use of water be prevented, and that the conservation of such waters is to be exercised with a view to the reasonable and beneficial use thereof in the interest of the people and for the public welfare. The right to water or to the use or flow of water in or from any natural stream or water course in this State is and shall be limitcd to sueh water as shall be reasonably required for the beneficial use to be served, and such right does not and shall not extend to the waste or unreasonable use or unreasonablc method of use or unreasonable method of diversion of water. Riparian rights in a stream or water course attach to, but to no more than so much of the flow thereof as inay be required or used consistently with this section, for the purposes for which such lands are, or may be made adaptable, in view of such reasonable and beneficial uses; provided, however, that nothing herein contained shall be construed as depriving any riparian owner of the reasonable use of water of the stream to which the owner's land is riparian under reasonable methods of diversion and use, or as depriving any appropriator of water to which the appropriator is lawfully entitled. This section shall be self-executing, and the Legislature may also enact laws in the furtherance of the policy in this section contained.

53. Meridian, Ltd. v. City \& County of San Francisco, 13 Cal. 2d 424, 445, 447, 90 P.2d 537, $547-48$ (1939).

54. Id. at 445, 90 P.2d at 547; CAL. WATER CODE \& 1201 (Deering 1977).

55. See generally 1 ROGERS \& Nichols, supra note 9, \$\$ 226-244.

56. Id. $\S 228$.

57. See E. Clemens Horst Co. v. Tarr Mining Co., 174 Cal. 430, 436-37, I63 P. 492, 495 (1917) (prescriptive right vests adverse user with perfect, unassailable right, good against the world); CAL. CIv. CODE $\S 1007$ (West 1980 Supp.) (prescriptive title is "sufficient against all").

58. 1 Rogers \& Nichols, supra note $9, \S 234$.

Two theories have been used to justify prescriptive water rights in California. The first is based upon the fiction of a presumed lost grant. Faulkner v. Rondoni, 104 Cal. 140, 146, 37 P. 
the true owner, ${ }^{59}$ who must have actual notice of the diversion or be chargeable with constructive or inquiry notice. ${ }^{60}$ To the extent taxes are assessed agamst the water right, they must be paid by the adverse claimant. ${ }^{61}$ Finally, because of the constitutional anti-waste policy, the water must be used for a reasonable and beneficial purpose. ${ }^{62}$

Before the 1928 constitutional amendment, a riparian was entitled to enjoin any appropriation that dininished the flow past his land. ${ }^{63}$ Accordingly, any upstream diversion ${ }^{64}$ was automatically adverse to lower riparian owners. If continued openly and under clainı of right for five years, the diversion would ripen into a prescriptive right. ${ }^{65} \mathrm{Un}$ til 1928, this was the only nonconsensual inethod by which an appropriator could protect his water supply agamst the paramount rights of riparian owners. ${ }^{66}$

The 1928 annendment limited the riparian right to only so inuch of the stream's flow as could be used for a reasonable and beneficial purpose. ${ }^{67}$ This limitation had a dircct impact on the prescriptive rights doctrine. Because the riparian owner could no longer imsist on an undimmished flow past his land, an upstream appropriation was no

883, 886 (1894); Allen v. San Jose Land \& Water Co., 92 Cal. 138, 141, 28 P. 215, 216 (1891). The more inodern view is that prescriptive water rights are perfected through the running of the statute of limitations. Beckett v. City of Petaluma, 171 Cal. 309, 316, 153 P. 20, 23 (1915) (recognizing presumed grant theory obsolete after California legislature adopted CAL. Civ. CODE $\$ 1007$ ). But see Pabst v. Finmand, $190 \mathrm{Cal}$. 124, 129-30, 211 P. 11, 13 (1922) (relying on presumed grant theory). See generally 1 Rogers \& Nichols, supra note 9, \& 226 at 326; Craig, Prescriptive Water Rights in California and the Necessity for a Valid Statutory Appropriation, 42 CALIF. L. REv. 219, 219-20 (1954) [hereinafter cited as Craig].

59. I ROGERS \& Nichols $\$ 239$.

60. Id. $\S 238$.

61. Id. $\$ 243$.

62. See Moore v. California Or. Power Co., 22 Cal. 2d 725, 737, 140 P.2d 798, 805 (1943); 1 Rogers \& Nichols, supra note $9, \$ 229$, at 331 .

63. See note 50 and accompanying text supra.

64. The general rule has been that prescription cannot run upstream against an upper riparian in favor of a lower riparian or appropriator, since taking by the lower user does not interfere with the flow above or invade any right of the upper owner. Bathgate v. City of Irvine, $126 \mathrm{Cal}$. $135,140,58$ P. 442, 444 (1899). However, where the upper owner is an appropriator, a lower appropriator can perfect a prescriptive right. City of Antioch v. Williams lrr. Dist., $188 \mathrm{Cal}$. 451, 457, 205 P. 688, 691 (1922).

65. 1 Rogers \& Nichols, supra note $9, \S 228$.

66. See id. at $\S 180$; WITKIN, supra note $25, \S 579$.

Because the prescriptive rights doctrine allowed an appropriator to protect his water supply against the paranount claims of riparian owners, it has been credited with facilitating development of Cahifornia's vast nonriparian agricultural lands. Irrigation of those lands would have been impossible had riparian rights been inviolate. See Craig, supra note 58, at 233; Address by California Supreme Court Chief Justice Lucien Shaw, The Development of the Law of Waters in the West (August 9, 1922), reprinted in 10 CALIF. L. REv. 443, 455-56, 189 Cal. 779, 792-93 (1922) [hereinafter cited as Shaw].

67. See notes $52 \& 53$ and accompanying text supra. 
longer an automatic trespass on the riparian right. ${ }^{68}$ Consequently, an appropriator could no longer perfect a prescriptive right simply by using water that the riparian did not curently need. ${ }^{69}$ Rather, in order to be adverse to the riparian right, the diversion had to interfere with the riparian's reasonable and beneficial use. ${ }^{70}$

The current status of the prescriptive rights doctrine in California is uncertaim. ${ }^{71}$ Adoption of section 1225, which requires a permit to "appropriate or use water subject to appropriation,"72 generated debate over whether a prescriptive right can be perfected without a permit. Only a handful of judicial opinions inention the controversy when discussing prescriptive rights. ${ }^{73}$ The debate has been more heated in other

68. See text accompanying note 51 supra.

69. City of Pasadena v. City of Alhambra, 33 Cal. 2d 908, 926, 207 P.2d 17, 29 (1949); Bloss v. Rahilly, 16 Cal. 2d 70, 78-79, 104 P.2d 1049, 1053 (1940).

70. See 1 Rogers \& Nichols, supra note $9, \S 231$.

This limitation on the riparian right reduced dependence on the prescriptive rights doctrine. It was more difficult to perfect a prescriptive right, since an appropriator's diversion of water was no longer automatically adverse to the riparian. Moreover, because the riparian could no longcr claim absolute priority, an injunction suit in whieh a prescriptive right might be asserted as a defense was less hikely. Reduced reliance on the doctrine in turn led to a decline in the number of water rights cases, which previously had been disproportionately high. See Shaw, supra note 66, at $444,189 \mathrm{Cal}$. at 780 (as of 1922, California courts had decided more water rights cases than any other type of case). It may also explain why it was not until 1980 that the court finally faced the issue of whether the prescriptive rights doctrine had survived the enactment of the Water Code.

71. The California Supreme Court is at least partially responsible for the uncertainty. In 1913 the California legislature attempted to eliminate the multitude of prescriptive rights claims by eliminating dormant riparian rights. See California State Primting Office, Amendments to Constitution and Proposed Statutes with Arguments Respecting the Same, General Election on Tuesday, November 3, 1914, at 49 (1914). The Water Commission Act declared that nonuse for a period of ten years would result in loss of a dormant riparian right. 1913 Cal. Stats., ch. 586, \& 11, at 1017-18. As the experience of other states attests, abolishing dormant riparian rights would have largely eliminated the need for the prescriptive water rights doctrine. See Hutchins-1974, supra note 46, at 401-05. The California Supreme Court, however, declared the atteinpt to abolish dormant riparian rights unconstitutional. Tulare lrr. Dist. v. Lindsay-Strathmore Irr. Dist., 3 Cal. 2d 489, 530, 45 P.2d 972, 986 (1935).

72. CAL. WATER CODE $§ 1225$ (Deering 1977).

73. See Kletzing, Prescriptive Water Rights in California: Is Application a Prerequisite?, 39 CALIF. L. Rev. 369, 375 (1951) [hereinafter cited as Kletzing]. In Meridian, Ltd., v. City \& County of San Francisco, 13 Cal. 2d 424, 450, 90 P.2d 537, 550 (1939), the court commented that since the Board was authorized by the Water Commission Act to enjoin any unauthorized diversion of water, " $[t]$ here need be no apprehension therefore lest rights become vested, by prescription or otherwise, in an excessive use of water or in a use for unauthorized purposes." In Crane v. Stevinson, 5 Cal. 2d 387, 398, 54 P.2d 1100, $1105-06$ (1936), the court assumed, without discussing contrary arguments, that a permit was a prerequisite to a prescriptive right, but denied the prescriptive claim on other grounds. In Chuck v. Alves, 124 Cal. App. 2d 144, 145, 268 P.2d 94, 95 (1st Dist. 1954), the issue was raised by the parties but was not considered by the court because of its conclusion that no question of prescriptive rights was involved. Finally, in Hudson v. West, 47 Cal. 2d 823, 827, 306 P.2d 807, 808 (1957), the Board filed an anicus brief arguing that a permit was a prerequisite to the defendant's preseriptive claim, but the court declined to consider the issue, pointing out that it had not been raised by the parties and that the state's interests were not prejudiced since it was not a party. 
forums, however, with commentators equally divided on the issue. One side contends that prescriptive rights are simply a subclass of appropriative rights. ${ }^{74}$ They conclude that smce the permit system is now the exclusive method of acquiring an appropriative right, an appropriation without a permit can never ripen into prescriptive title. ${ }^{75}$ The other view argues that prescriptive rights are a separate category of water rights that should not be governed by section 1225's permit requireinent. ${ }^{76}$ They maintain that since prescription of land has been excepted from the recording acts, prescriptive water rights should be outside the analogous permit system. ${ }^{77}$ Both views influenced the divided Shirokow court.

\section{The Governor's Commission to Review California Water Rights Law: Policy Suggestions and Judicial Response}

The Governor's Commission to Review Cahforina Water Rights Law, established in response to the $1976-77$ drought, ${ }^{78}$ concluded that the parallel water rights doctrines have created uncertainty and inefficiency. ${ }^{79}$ It identified three sources of confusion: nonstatutory rights are not registered with the Board, ${ }^{80}$ riparian rights need not be exercised to be valid, ${ }^{81}$ and water disputes are settled case by case. ${ }^{82}$ To remedy these problems and enhance the efficiency of water resource

74. See, e.g., Hutchins, supra note 21, at 332-33; Hutchins-1974, supra note 46, at 416-17; Craig, supra note 58, at 224-25.

75. See, e.g., Craig, supra note 58 , at 230.

76. This view finds some support in the fact that the Water Commission Act did not expressly abolish the prescriptive rights doctrine, although a proposed version of the Act would have done so. That version made it a misdemeanor to use water not claimed before 1914 without a permit or heense from the Board and declared that such use would confer no right to the water. 1913 Calif. Assembly Bill 642, § 39 as introduced January 23, 1913. However, the Act as passed by the legislature and approved by voter referendum provided only that diversion or use of water without a permit would constitute a trespass which the Board could file suit to enjoin. $1913 \mathrm{Cal}$. Stats., ch. 586, § 38, p. 1032 (current version at CAL. WATER CODE $§ 1052$ (Deering 1977)).

77. Kletzing, supra note 73, at 371; Weil, Unregistered Water Appropriations at Law and in Equity, 14 CALIF. L. Rev. 427 (1926).

The Board originally took the position that no prescriptive water right could be acquired without a permit. Hutchins, supra note 21, at 335 (quoting Calif. State Dept. of Public Works, Rules, Regulations, and Information Pertaining to Appropriation of Water in California 38 (1956)). The Board later softened its position, conceding that an unauthorized user could, by adverse use "under certain circuunstances, foreclose objection by those who have been adversely affected," but inaintaining, nevertheless, that the nonauthorized user could never acquire a right to "prevent diversions by others which deplete the supply of water available to him." REGULATIONS AND INFORMATION, supra note 20, at 68.

78. GOVERNOR's COMMISSION, supra note 23 , at 2.

79. Id. at 17-25.

80. Id. at 17-18. These nonstatutory rights include pre-1914 appropriative rights, prescriptive rights and riparian rights. Id. at 17 .

81. Id. at 18-21.

82. Id. at 21 . 
allocation, the Commission proposed several legislative changes. ${ }^{83}$ The Board's authority to resolve water rights disputes would be expanded. ${ }^{84}$ It would also be permitted to quantify unexercised riparian rights and assign them a lower priority than active water uses. ${ }^{85}$ The Commission also recommended registration of all nonstatutory rights and complete prospective abolition of the prescriptive water rights doctrine. $^{86}$

The California Supreme Court's first response to the Commission's recommendations appeared in In re Waters of Long Valley Creek Stream System ${ }^{87}$ the following year. By a margin of four to three, the court held that the Board has the authority in a statutory adjudication proceeding - a special procedure authorized by the Water Code in which the Board determines all water rights $\mathrm{m}$ an entire stream system $^{88}$ - to quantify and assign lower priority to a riparian's right to future use of water. ${ }^{89}$ The majority decision strongly endorsed the policy considerations that underlay the Commission's recommendations. ${ }^{90}$ Indeed, the only practical difference between the Commission's approach and the Long Valley holding was that the Commission thought legislation would be necessary to give the Board this authority while the court concluded that the necessary authority already existed. The court's unqualified acceptance of the Commission's recommendation is particularly striking since, only six months before the Commission issued its report, the court unamimously refused to hear a district court of appeal case that held the Board could never limit unexercised riparian rights. ${ }^{91}$ The court's analysis in Shirokow reflects a similar deference to the Commission's policy considerations. ${ }^{92}$

83. None of the Commission's proposals have yet been enacted into law. Telephone interview with Evan Nossoff, Public Affairs Office, State Water Resources Control Board, Sacramento, California, April 14, 1981.

84. Governor's COMmission, supra note 23, at 27-30.

85. Id. at 27-30.

86. Id. at 31 .

87. 25 Cal. 3d 339, 599 P.2d 656, 158 Cal. Rptr. 350 (1979).

88. See CAL. WATER CODE $\S \S 2500-2900$ (Deering 1977).

89. 25 Cal. $3 \mathrm{~d}$ at $348-49,599$ P.2d at 661,158 Cal. Rptr. at 355.

90. Id. at 355-57, 599 P.2d at 666-67, 158 Cal. Rptr. at 360-61.

91. In re Waters of Soquel Creek Stream Sys., 79 Cal. App. 3d 682, 689, 145 Cal. Rptr. 146, 150 (1st Dist. 1978). The court's decision that the Board could not limit riparian rights was based on the fact that these rights are protected by the California Constitution. Id. The California Supreme Court's denial of hearing was noted in Justice Richardson's Long Valley dissent. 25 Cal. 3d at 363, 599 P.2d at 672, 158 Cal. Rptr. at 365 (Richardson, J., concurring and dissenting).

92. 26 Cal. 3d at 309-10 \& n.12, 605 P.2d at $865 \&$ n.12, 162 Cal. Rptr. $36 \&$ n.12. See text accompanying note 159 infra. 
III

\section{The Court's ANalysis}

\section{A. Scope of Section 1052}

To determine the scope of the Board's authority to seek a remedial injunction under section $1052,{ }^{93}$ the court looked to the section's context in division two of the Water Code. ${ }^{94}$ Division two was designed to provide a "coinprehensive scheme for the appropriation of water." 95 Thus, if Shirokow diverted "water subject to appropriation," division two's provisions governed and the state was entitled to an injunction. ${ }^{96}$

Although "water subject to appropriation" is defined in section $1201,{ }^{97}$ the court did not look to its language. Instead, it noted four policies behind the Water Code and the 1928 constitutional amendment: ${ }^{98}$ (1) all water within the state is the property of the people; ${ }^{99}(2)$ the people have a paramount interest in the use of water; ${ }^{100}$ (3) the state should control water development in order to promote the greatest public benefit; ${ }^{101}$ and (4) the state's water resources should be put to the maximuin reasonable and beneficial use. ${ }^{102}$ These policies, "together with the [Water Code's] comprehensive regulatory scheine . . . deinonstrate a legislative intent to vest in the board expansive powers to safeguard the scarce water resources of the state." 103 Thus, unless the water

93. The Board's authority under $\S 1052$ was a question of first impression. The only other reported case applying $\S 1052$ is State v. Hansen, 189 Cal. App. 2d 604, 610, 11 Cal. Rptr. 335, 339 (4th Dist. 1961) (alternative holding). In Hansen, the state enjoined the defendant's diversion of water from a spring on state-owned land. As the court acknowledged, $\$ 1052$ was not strictly applicable; since the water did not naturally fiow off the land, it was not subject to appropriation. Id.

94. Division two codifies the appropriation procedures. CAL. WATER CoDE $\$ \$ 1200-1706$ (Deering 1977). It also contains provisions relating to the Board's general admmistrative responsibilities, id. $\$ \$ 1000-1106$, and the procedure for resolving conflicting water right claims, id. $\$ \$ 2000-2900$.

The $\$ 1052$ remedy is only available with respect to water subject to division two's provisions. 26 Cal. 3d at 306, 605 P.2d at 862, 162 Cal. Rptr. at 33 (quoting CAL. WATER CODE \& 1052 (Deering 1977)). The text of $\S 1052$ is set forth in note 5 supra.

95. 26 Cal. $3 d$ at 306,605 P.2d at 863,162 Cal. Rptr. at 33.

96. Id. at 306,605 P.2d at 863,162 Cal. Rptr. at 33-34.

97. CAL. WATER CODE $\S 1201$ (Deering 1977) provides:

All water flowing im any natural channel, excepting so far as it has been or is being applied to useful and beneficial purposes upon, or in so far as it is or may be reasonably needed for useful and beneficial purposes upon lands riparian thereto, or otherwise appropriated, is hereby declared to be public water of the State and subject to appropriation in accordance with the provisions of this code.

98. $26 \mathrm{Cal} .3 \mathrm{~d}$ at $308-09,605$ P.2d at $865,162 \mathrm{Cal}$. Rptr. at 35.

99. CAL. WATER CODE $\S 102$ (Deering 1977).

100. Id. $\$ 104$.

101. Id. $\$ 105$.

102. See note 52 supra and note I26 infra; CAL. Const. art. X, \& 2; CAL. WATER CODE $\S 100$ (Deering 1977).

103. $26 \mathrm{Cal}$. $3 \mathrm{~d}$ at 309,605 P.2d at 864,126 Cal. Rptr. at 35 . 
user has a permit, a riparian right, or a pre-1914 appropriative or prescriptive right, the Board may enjoin the use under section 1052. ${ }^{104}$ Since Shirokow had no permit and since his seasonal water storage could qualify neither as a proper riparian use ${ }^{105}$ nor as a pre-1914 appropriation, the state was entitled to enjoin his use. ${ }^{106}$

The court buttressed its conclusion with three additional policy arguments. First, "the salutary effects of the comprehensive systcm of water rights administration would be imperiled if the board were powerless to enjoin an adverse use of water which the board had previously otherwise allocated, or desired to allocate, in the public imterest."107 Second, prescriptive rights would lead to uncertainty as to what water was available for appropriation. ${ }^{108}$ This uncertainty would make it difficult to ensure that the state's water resources were being put to maximum beneficial use. ${ }^{109}$ Third, allowing the state to enjoin an unauthorized use would not result in waste, for beneficial users who originally rehed on prescription could apply for permits. The Board would probably grant such a permit unless it determmed that the particular use did not serve the greatest public benefit. ${ }^{10}$ Arbitrary denial of a permit could be corrected by judicial review. ${ }^{11}$

In dissent, Justice Clark argued that the state was not entitlcd to enjoin Shirokow's diversion. He questioned whether the water Shirokow had been diverting would be used if Shirokow's use ceased. ${ }^{112}$ Justice Clark poimted out that the Cahfornia Constitution prohibits water waste, ${ }^{113}$ and concluded that under this constitutional policy, "[t]he board should not be permitted to require water wastage as a means to compel applications for permits to appropriate from those persons already making reasonable and beneficial use of water."114

104. Id. at 309, 605 P.2d at 865,126 Cal. Rptr. at 35 .

105. Id. at $307 \mathrm{n} .7,605$ P.2d at 864 n.7, 162 Cal. Rptr. at 34 n.7. See note 47 and accompanying text supra.

106. 26 Cal. $3 d$ at 309,605 P.2d at 865,162 Cal. Rptr. at 36.

107. 26 Cal. $3 d$ at 309-10, 605 P.2d at 865, 162 Cal. Rptr. at 36.

108. GOVERNOR's COMMISSION, supra note 23, at 31.

109. $26 \mathrm{Cal} .3 \mathrm{~d}$ at 310,605 P.2d at 865,162 Cal. Rptr. at 36.

110. Id.

111. Id. See Cal. Water Code $\$ \S 1360,1412,1615$ (Deering 1977) (providing for judicial review by writ of mandate to inquire into validity of Board action).

112. 26 Cal. 3d at 317, 605 P.2d at 869-70, 162 Cal. Rptr. at 40-41 (Clark, J., concurring and dissenting).

113. Id. at 314-15, 605 P.2d at 868, 162 Cal. Rptr. at 39 (Clark, J., concurring and dissenting). The anti-waste provision to which Justice Clark referred is $C_{A L}$. Const. art. $X, \S 2$, set forth in full at note 52 supra.

114. 26 Cal. $3 d$ at 316, 605 P.2d at 869, 162 Cal. Rptr. at 40 (Clark, J., concurring and dissenting). 


\section{B. Prescriptive Rights}

The entire court agreed that Shirokow had not perfected a prescriptive right. The dissent argued that such a right remained a possibility, however, while the majority addressed the point only for the sake of argument. This split reflected different attitudes toward prescriptive water rights in general.

Justice Mosk's majority opinion offered two reasons why Shirokow's clain of a prescriptive right would fail even if a permit were not required. First, property rights held by the state in a governmental, nonproprietary capacity and dedicated to public use cannot be lost through adverse possession. ${ }^{15}$ Second, Shirokow failed to meet one of the essential tests of a prescriptive right: he did not prove that his use invaded another's right to the water. ${ }^{116}$ Even if he had identified downstream users with paramount rights, the court had no jurisdiction to determine Shirokow's rights as against them because they were not parties to the action. ${ }^{117}$

Although Justice Clark agreed with the inajority that Shirokow had not perfected a prescriptive right, he disagreed with what he perceived as the majority's abolition of post-1913 prescriptive rights. ${ }^{118}$ Since the court had repeatedly affirmed such rights, the issue was already settled." ${ }^{119}$ Moreover, since only surplus waters are "subject to appropriation" 120 and prescriptive rights may only be asserted against

115. See, e.g., Henry Cowell Lime \& Cement Co. v. State, 18 Cal. 2d 169, 172, 114 P.2d 331, 332-33 (1941); City of San Diego v. Cuyamaca Water Co., 209 Cal. 105, 136, 287 P. 475, 490 (1930).

Waters in excess of the needs of riparians "constitute the public waters of the state to be used, regulated and controlled by the state or under its direction." Meridian, Ltd. v. City and County of San Francisco, 13 Cal. 2d 424, 445, 90 P.2d 537, 547 (1939). The Board is deemed to perform a governmental function in exercising the regulatory functions of the state in the field of water resources. Cal. Water CODE $\$ \$ 174,1050$ (Deering 1977 \& Supp. 1980). See also Cal. Civ. CODE $\S 1007$ (West 1954) (no prescriptive rights can be acquired in property dedicated or owned by the state). The court could not rely on CAL. CIV. CODE $\S 1007$ because it was not made applicable to the state until 1968. 1968 Cal. Stats., ch. 1112, § 1, at 2125-26. Had Shirokow satisfied the prescriptive rights elements, his right could have vested before 1968 , since the diversion began before 1960.

116. 26 Cal. 3d at 312, 605 P.2d at 867, 162 Cal. Rptr. at 37-38. Before a use can be termed prescriptive, lower landowners must have notice of the adverse use. See Pabst v. Findmand, 190 Cal. 124, 130, 211 P. 11, 13 (1922). The prescriptive claimant bears the burden of proving notice. See Skelly v. Cowell, 37 Cal. App. 214, 217, 173 P. 609, 609 (1st Dist. 1918).

117. 26 Cal. 3d at 312, 60S P.2d at 867, 162 Cal. Rptr. at 38. See In re Waters of Long Valley Creek Stream Sys., 25 Cal. 3d 339, 347, 599 P.2d 656, 660-61, 158 Cal. Rptr. 350, 354 (1979) (water rights litigation determines only relative rights of parties).

118. 26 Cal. 3d at 318-19, 605 P.2d at 870-71, 162 Cal. Rptr. at 41-42 (Clark, J., concurring and dissenting). The majority disagreed with this characterization. Id. at $312 \mathrm{n} .15,605$ P.2d at 867 n. 15,162 Cal. Rptr. at 38 n. 15.

119. Id. at 319, 605 P.2d at 871,162 Cal. Rptr. at 42 (Clark, J., concurring and dissenting). See, e.g., Moore v. California Or. Power Co., 22 Cal. 2d 725, 735, 140 P.2d 798, 804 (1943).

120. Cal. Water CODE $\S 1225$ (Deering 1977). 
water belonging to someone, "[t]he statutes have no relation to property rights acquired by prescription because prescriptive rights may not be acquired in surplus waters." 121

Justice Clark also rejected the policy behind the majority opinion. Any uncertainty caused by the nonregistration of prescriptive rights is insignificant because riparian rights are not registered either. ${ }^{122} \mathrm{He}$ also argued that beneficial prescriptive users, contrary to the majority's opinion, would probably not be able to acquire permits because surplus water is relatively scarce. ${ }^{123}$ Fimally, he feared that abrogating prescriptive rights acquired after 1913 might subject governinental agencies holding such rights to riparian claims in imverse condenınation. ${ }^{124}$

\section{IV}

\section{THE EFFECT OF CALIFornia's Constitutional Water Conservation Policy on Section 1052}

The California Constitution requires that water be put to its maximum reasonable and beneficial use. ${ }^{125}$ However, the Shirokow court did not consider the possibility that the water would no longer be reasonably and beneficially used once Shirokow stopped using it. ${ }^{126}$ A

121. 26 Cal. $3 \mathrm{~d}$ at 320, 605 P.2d at 872, 162 Cal. Rptr. at 43 (Clark, J., concurring and dissenting).

122. Id. at 321, 605 P.2d at 872, 162 Cal. Rptr. at 43 (Clark, J., concurring and dissenting).

123. Id.

124. Id. at 321 n.6, 605 P.2d at 872 n.6, 162 Cal. Rptr. at 43 n.6 (Clark, J., concurring and dissenting).

125. CAL. Const. art. X, $\S 2$, set forth at note 52 supra. Similar limitations are imposed statutorily by CAL. WATER CODE $§ 100$ (Deering 1977).

126. See text accompanying notes 112-14 supra. As Justice Clark's dissent points out, the stipulated facts suggest that enjoining Shirokow's use would result in waste of the water. 26 Cal. 3d at 317, 605 P.2d at 868-70, 162 Cal. Rptr. at 40-41 (dissenting opinion). It seems unlikely that downstream riparians would use the water since it arrived in the rainy winter months when water is generally most abundant and least needed. Moreover, the decision does not indieate whether the Board intended to allocate or had allocated the water to another. The only refercnce in the opinion as to what became of water from Arnold Creek is that it eventually reached the federal Central Valley Project. Id. at 305, 605 P.2d at 862, 162 Cal. Rptr. at 33. The federal government could not legally divert the water without an appropriation permit from the Board. California v. United States, 558 F.2d 1347, 1351 (9th Cir. 1977), rev'd on other grounds, 438 U.S. 645 (1978). Nothing in the case suggests the United States had a permit. To the contrary, the Board's willingness to grant Shirokow a permit if he complied with a brush removal requirement, see text accompanying note 11 supra, indicates that the water had not been allocatcd to anothcr, since available unappropriated water is a prerequisite for a permit. CAL. WATER CODE $\$ 1375$ (Dccring 1977).

Even assuming that the water impounded by Shirokow would be beneficially used by the Central Valley Project, that inight not be the most beneficial and reasonable use of the water as required by CAL. Const. art. X, $\S 2$ and Cal. Water CODE $\S 100$ (Deering 1977). Seepage and evaporative losses en route might make allocation to the Central Valley Project an unreasonable use. See Erickson v. Queen Valley Ranch Co., 22 Cal. App. 3d 578, 584-85, 99 Cal. Rptr. 446, 450 (3d Dist. 1971) (seepage and evaporative losses in transporting water two and a half miles to plaintiff's ranch is not reasonable use of water). Since the adoption of the 1928 constitutional amendment, water use must not only be beneficial but reasonable as well. See, e.g., Joslin v. 
section 1052 injunction barring his use might therefore conflict with the California Constitution.

This note concludes that Shirokow properly allowed the state to enjoin Shirokow's unauthorized water use without first proving that no water waste would result. It argues, however, that the California Constitution requires a court to allow an unauthorized water user to present, as an affirniative defense, evidence that the water would be wasted if he did not use it. ${ }^{127}$

\section{A. Unlike a Private Party, the State Need Not Prove Lack of Waste to Enjoin Unauthorized Water Use}

In 1928, Cahfornia voters approved an amendment to the state's constitution requiring the state's water resources to "be put to beneficial use to the fullest extent of which they are capable." 128 The amendment was adopted in direct response to the California Supreme Court's invalidation ${ }^{129}$ of the legislature's attempt, in the 1913 Water Commission Act, to limit the riparian right to reasonable use. ${ }^{130}$ Water waste was now condemned by the California Constitution. ${ }^{131}$

Thus, a private party who seeks to enjoin an encroachment on his paramount water right must prove that the injunction will not waste the state's water resources. ${ }^{132}$ This is appropriate because an injunction is

Marin Mun. Water Dist., 67 Cal. 2d 132, 142-43, 429 P.2d 889, 896, 60 Cal. Rptr. 377, 384 (1967) (use of stream to deposit rock and gravel for commercial purposes is beneficial but not reasonable use); People v. Forni, 54 Cal. App. 3d 743, 751-52, 126 Cal. Rptr. 851, 856-57 (1st Dist. 1976) (use of water for frost protection during shortage period is beneficial but not reasonable use). See generally C. LEE, Governor's COMM'N TO Review California WATER Rights Law, StafF Paper No. 3, Legal Aspects of WATER Conservation in California at 7-8 (1977) [heteinafter cited as LEE].

127. In the instant case, the defendant failed to raise and therefore waived the possible constitutional violation. Hershey v. Reclamation Dist., 200 Cal. 550, 564, 254 P. 542, 547 (1927); Preston v. Municipal Court, 188 Cal. App. 2d 76, 82, 10 Cal. Rptr. 301, 304 (1st Dist. 1961).

128. CAL. Const. art. X, $\S 2$, set forth in full at note 52 supra.

129. Herminghaus v. Southern Cal. Edison Co., 200 Cal. 81, 252 P. 607 (1926), cert. dismissed, 275 U.S. 486 (1927). Herminghous permitted a riparian landowner to enjoin an upstream appropriator from constructing reservoirs for power generation, despite the fact that the claimed riparian right required that $97 \%$ of the stream's flow pass the riparian land unused. Id. at 97,252 P. at 613-14. See Cal. State Printing Office, Amendments to Constitution and Proposed Statutes, California General Election of Tuesday, November 6, 1928, at 14 (1928).

130. Herminghaus v. Southern Cal. Edison Co., 200 Cal. at 117-19, 252 P. at 621-23.

131. See LEE, supra note 126 , at 6 .

132. See, e.g., Stevinson Water Dist. v. Roduner, 36 Cal. 2d 264, 270, 223 P.2d 209, 212-13 (1950); City of Pasadena v. City of Alhambra, 33 Cal. 2d 908, 926, 207 P.2d 17, 28 (1949); Meridian, Ltd. v. City \& County of San Francisco, 13 Cal. 2d 424, 447, 90 P.2d 537, 548 (1939); Chow v. City of Santa Barbara, 217 Cal. 673, 694-700, 22 P.2d 5, 13-16 (1933).

The plaintiff must also demonstrate that he will use the water himself for a reasonable and beneficial purpose. Carlsbad Mut. Water Co. v. San Luis Rey Dev. Co., 78 Cal. App. 2d 900, 914, 178 P.2d 844, 853 (4th Dist. 1947). If the adverse use does not materially diminish the water supply that plaimtiff can presently put to reasonable and beneficial use, the plaintiff is not entitled 
an equitable remedy. ${ }^{133}$ It would be inequitable to restrain diversion of water where the plaintiff would not be using the water and the diversion, rather than injuring the plaintiff's land, would greatly benefit another. ${ }^{134}$

In contrast with private parties, however, the Board does not appeal to the court's equitable powers. Section 1052 expressly authorizes the Board to seek an injunction. When an ijunction is authorized by a regulatory statute, the court is not bound by principles that apply to private suits in equity. ${ }^{135}$ Thus, the Board should not have to prove that no water waste will result if an injunction issues.

The 1913 Water Cominission Act, ${ }^{136}$ from which the present section 1052 derives, made the Board responsible for determining what use of the state's water resources would best serve the public interest. ${ }^{137}$ The Board thus has a legislative mandate to act as the central decisionmaker with respect to state water planning, policy and inanagement. In deference to this mandate, a court should accord great weight to the Board's water inanagement decisions, including the seeking of injunctions under section 1052.

This judicial deference is supported by the Board's duty to take "all appropriate proceedings or actions . . . to prevent waste." 138 Absent proof to the contrary, a court inust presuine that the Board has

to an injunction but only to a judgment declaring his preferential right so that the adverse use cannot ripen into a prescriptive right. Peabody v. City of Vallejo, 2 Cal. 2d 351, 374-75, 40 P.2d 486, 494-95 (1935).

Before the 1928 constitutional amendment, if an adverse use would ripen into a prescriptive right and deprive the owner of his paramount property right, no actual present damage had to be shown; the injunction would issue automatically. See Hutchins, supra note 21, at 278.

133. Only in equity may the holder of a water right restrain another from infringing it. Tuolumne Water Co. v. Chapman, 8 Cal. 392, 397 (1857). See 2 Hutchins-1974, supra note 46, at 225.

134. Meridian, Ltd. v. City \& County of San Francisco, 13 Cal. 2d 424, 447, 90 P.2d 537, 548 (1939); Chow v. City of Santa Barbara, 217 Cal. 673, 690, 22 P.2d 5, 11-12 (1933).

135. United States v. Diapulse Corp. of America, 457 F.2d 25, $27-28$ (2d Cir. 1972); State v. O.K. Transfer Co., 215 Or. 8, 15-17, 330 P.2d 510, 513-14 (1958). See Bradford v. SEC, 278 F.2d 566,567 (9th Cir. 1960) (per curiam) (proof of irreparable injury not required in injunction action authorized by statute); Bowles v. Huff, 146 F.2d 428, 430 (9th Cir. 1944) (proof of irreparable injury and absence of adequate remedy at law not nccessary when injunction authorized by statute); American Fruit Growers v. United States, 105 F.2d 722, 725 (9th Cir. 1939); Arizona State Bd. of Dental Exauniners v. Hyder, 114 Ariz. 544, 546, 562 P.2d 717, 719 (1977) (where state agency authorized to restrain violation of law, irreparable injury need not be shown); Comment, Developments in the Law-Injunctions, 78 HARv. L. REv. 994, 1059 (1965) (effect of statute on availability of preliminary injunction). But see Frost v. City of Los Angeles, 181 Cal. 22, 30, 183 P. 342, 346 (1919) (when statute authorizes private citizen to maintain action to enjoin public nuisance, it is presumed legislature did not intend to change principles of equity regarding injunctions) (dictuin).

136. 1913 Cal. Stats., ch. 586, § 38, at 29.

137. Bloss v. Rahilly, 16 Cal. 2d 70, 75, 104 P.2d 1049, 1051 (1940); Meridian, Ltd. v. City \& County of San Francisco, 13 Cal. 2d 424, 445, 450, 90 P.2d 537, 547, 550 (1939).

138. Cal. Water Code $\S 275$ (Deering 1977). 
properly performed its official function. ${ }^{139}$ The Board's statutory duty, coupled with its special expertise ${ }^{140}$ and factfinding resources, should lead a court to presume that the Board has already determined that no waste will result from the injunction it seeks. Where the defendant introduces no evidence suggesting waste, a court should defer to the Board's express or implied finding. ${ }^{141}$

\section{B. Proof of Waste Should Be Recognized as an Affirmative Defense to a Section 1052 Injunction}

Section 1052 does not compel a court to issue an injunction when the state has made a prima facie case of unlawful appropriation. Statutes authorizing administrative agencies to seek injunctive relief are generally construed to give courts wide latitude in granting relief. ${ }^{142}$ California courts must consider the public policies at stake in determining the availability of injunctions, even where the remedy is expressly authorized by statute. ${ }^{143}$ Since the constitutional water conservation policy applies to every use of water and every water right, ${ }^{144}$ using section 1052 to compel waste would clearly be unconstitutional. Interpreting the statute to permit proof of waste as an affirmative defense would avoid this constitutional problem. ${ }^{145}$

"Uncertainty as to the availability of water for appropriation"146

139. CAL. Evid. CODE $\S 664$ (West 1966) (statutory presumption that a state agency properly performs its official duties); CAL. WATER CODE $§ 1050$ (Deering 1980 Supp.) (the Board is deemed to perform a governmental function in carrying out its duties).

140. When expertise is relevant, the court operates with a handicap when it substitutes its judgment for that of an administrative agency. See Jaffe, Judicial Review: Question of Law, 69 HARV. L. Rev. 239, 264-65 (1955).

141. Because the occurrence of "waste" is a highly technical factual issue that courts are illequipped to resolve, see Environmental Defense Fund, Inc. v. East Bay Mun. Util. Dist., 26 Cal. 3d 183, 194, 605 P.2d 1, 6, 161 Cal. Rptr. 466, 471 (1980), the court would normally refer the issue to the Board for factual findings in any event. See CAL. WATER Code $\$ 2001$ (Deering 1977). However, CAL. WATER CODE $\S 2019$ (Deering 1977) provides that the Board's findings of fact are merely prima facie evidence and that a reviewing court inust hear evidence offered in rebuttal.

142. See, e.g., Hecht Co. v. Bowles, 321 U.S. 321, 327-28 (1943); Bowles v. Huff, 146 F.2d 428, 430 (9th Cir. 1944); Frost v. City of Los Angeles, 181 Cal. 22, 31, 183 P. 342,346 (1919) (dictum).

143. Loma Portal Civic Club v. American Airhines, Inc., 61 Cal. 2d 582, 588, 394 P.2d 548, 552, 39 Cal. Rptr. 708, 712 (1964).

144. Peabody v. City of Vallejo, 2 Cal. 2d 351, 367, 40 P.2d 486, 491 (1935). See, e.g., City of Los Angeles v. City of San Fernando, 14 Cal. 3d 199, 272-73, 537 P.2d 1250, 1303-04, 123 Cal. Rptr. 1, 54-55 (1975) (pueblo right); Stevinson Water Dist. v. Roduner, 36 Cal. 2d 264, 269-70, 223 P.2d 209, 212 (1950) (foreign waters); City of Pasadena v. City of Alhambra, 33 Cal. 2d 908, 92526, 207 P.2d 17, 28 (1949) (appropriative right); Stevens v. Oakdale Irr. Dist., 13 Cal. 2d 343, 351, 90 P.2d 58, 62 (1939) (right to recapture return flow from imported water).

145. See In re Waters of Long Valley Creek Streain Sys., 25 Cal. 3d 339, 349, 599 P.2d 656, 662, 158 Cal. Rptr. 350, 356 (1979) (statutes should be interpretcd to be consistent with constitution, rather than with another possible meaning in conflict with constitution).

146. 26 Cal. $3 \mathrm{~d}$ at 310,605 P.2d at 866,162 Cal. Rptr. at 36 . 
has weighed very heavily with the supreme court ${ }^{147}$ and the Governor's Commission. ${ }^{148}$ However, permitting an affirmative waste defense and allowing a reasonable and beneficial unauthorized use to contmue will not itself create uncertainty. Uncertainty stems not from the unsanctioncd diversion, but from the possibility that it might ripen into a prescriptive right agamst the state. ${ }^{149}$ Shirokow now precludes that possibility. The affirmative waste defense, if successful, would only permit temporary use of the water until the Board allocates it. ${ }^{150}$

Preparing and hearmg an affirmative defense takes time, and if the injunction is delaycd beyond the irrigation season, the remedy may be rendered useless. Because injunctive actions typically take inonths to prepare, file, and be heard anyway, however, ${ }^{151}$ denying an affirmative defense would not appreciably reduce the delay. The Governor's Commission preferred giving the Board authority to issue administrative cease and desist orders. ${ }^{152}$ Alternatively, upon a showing that the Board has allocates or intends to allocate the water to another, the Board could obtain a preliminary injunction agamst the unauthorized use. ${ }^{153}$

A successful affirmative defense to a section 1052 injunction would not necessarily require a second judicial action to enjoin the unauthorized use if the Board later wished to allocate the water to another. A court could simply mold its judgment to accommodate this possibility. ${ }^{154}$ The judgment could give the defendant a right to continue diverting water only until the Board allocates the water to another. A writ of assistance or a contempt proceeding could then be used, if necessary, to enforce the judgment. Alternatively, the court could retaim jurisdiction to issue the section 1052 injunction when the Board could show that waste would no longer result. ${ }^{155}$

Thus, an unauthorized appropriator would rarely choose to con-

147. Id, In re Waters of Long Valley Creek Stream Sys., 25 Cal. 3d 339, 354-57, 599 P.2d 656, 665-67, 158 Cal. Rptr. 350, 359-61 (1979).

148. GOVERNOR's COMmission, supra note 23, at 16-49.

149. 26 Cal. $3 \mathrm{~d}$ at $310 \mathrm{n} .12,605$ P.2d at $866 \mathrm{n} .12,162$ Cal. Rptr. at $36 \mathrm{n} .12$.

150. Cf. CAL. WATER CODE $\$ 1203$ (Deering 1977) (where municipality holds paramount water right but does not presently need all the water, any person who can use water beneficially may do so temporarily). But of. id. $\S 1462$ (Board may allocate water temporarily in excess of municipality's existing needs).

151. GOVERnOR's COMMission, supra note 23 , at 58 .

152. Id. at 59 .

153. Cal. Civ. Proc. Code $\S 527$ (West Supp. 1980) (authorizing prelimimary imjunctions).

154. Mitchell v. DeMario Jewelry, 361 U.S. 288, 291 (1959) (unless a statute expressly restricts the court's equitable powers, a court may exercise its inherent equitable powers to shape its decree).

155. "The retention of jurisdiction to meet future problems and changing conditions is recognized as an appropriate method of carrying out the policy of the state to utilize all water available." City of Pasadena v. City of Alhambra, 33 Cal. 2d 908, 937, 207 P.2d 17, 35 (1949). 
tinue using water without a permit since his future water right would always remain uncertain. The fragility and temporariness of the right that could be won through the affinnative defense would probably result in its being rarely used. In the ineantime, allowing an unauthorized appropriator to use surplus water would serve the public interest by insuring that the state's water resources are used to the maximum.

\section{$\mathrm{V}$}

\section{The Future of Prescriptive Rights}

The 1978 Governor's Commission recommended the wholesale statutory abolition of prescriptive rights. ${ }^{156}$ Shirokow never reached so far; it only eliminated the possibility of an adverse user perfecting a prescriptive right against the state. ${ }^{157}$ It left open "the question of whether and under what circunstances prescriptive rights im water may be perfected between private parties." 158 However, the court's respect for the Commission's conclusions and recommendations, as reflected in both Long Valley and Shirokow, ${ }^{159}$ indicates that the court eventually might abolish prescriptive rights between private parties as well. ${ }^{160}$

This Note argues that abolishing all prescriptive water rights would be unnecessary and unwise. The Commission's arguments

156. GOVERNOR's COMmission, note 23 supra, at 31-32.

157. Shirokow could also be read to state that one must always have a permit to divert water, even if the water is not subject to statutory appropriation because of paramount riparian claims. This reading is based on the court's broad statement that "[a]ny use other than [riparian and pre1914 appropriations] is, in our view, conditioned upon compliance with the appropriation procedures of division 2." $26 \mathrm{CaI}$. 3d at 309, 605 P.2d at 865, 162 Cal. Rptr. at 36 (citations omitted). However, this interpretation would place too much weight on dictum. The court was not convinced that Shirokow's use was hostile to any downstream riparian owners. Id. at 312,605 P.2d at 866,162 Cal. Rptr. at 37 . The water he used must be regarded as surplus water subject to appropriation. Use of such water without a permit may be enjoined under $\$ 1052$. Moreover, if the water were subject to superior riparian clains, the Board could not allocate it. In order to issue a permit, "[t]here must be unappropriated water available." CAL. WATER CODE $§ 1375$ (Deering 1977). Water "reasonably needed for useful and beneficial purposes upon [riparian] lands" is not available for appropriation. $I d . \$ 1201$. It would be illogical for the court to require a permit if the Board has no authority to grant one.

158. 26 Cal. 3d at $312 \mathrm{n} .15,605$ P.2d at $867 \mathrm{n} .15,162 \mathrm{Cal}$. Rptr. at $38 \mathrm{n} .15$ (emphasis added).

159. See text accompanying notes 87-92 supra.

160. The court probably would not abolish prescriptive rights between riparians. The Board conceded in Shirokow that the Water Commission Act should not deter a riparian from gaining a prescriptive right agamst another riparian. Amicus Curiae Brief for Department of Watcr Resources at 13, People v. Shirokow, 26 Cal. 3d 301, 605 P.2d 859, 162 Cal. Rptr. 30 (1980). See Moore v. California Or. Powcr Co., 22 Cal. 2d 725, 735, 140 P.2d 798, 804 (1943) (it is "wellestablished" in this state . . . that an upper riparian owner may acquire a prescriptive right to the waters of a stream as against a lower riparian owner by an advcrse use of said waters for the prescriptive period"). It is also settled law that prescriptive rights may be perfected in ground water, another category of water that has never been subject to the Water Code's appropriation procedures. City of Pasadena v. City of Alhambra, 33 Cal. 2d 908, 926, 207 P.2d 17, 29 (1949); CAL. WATER CODE $§ 1200$ (Deermg 1977). 
against prescriptive rights do not apply to riparian water. Private unauthorized appropriators should continue to be able to perfect prescriptive rights against riparians. ${ }^{161}$ Moreover, allowing a private party to assert prescriptive rights to water not properly used by a Board-licensed appropriator would not prejudice the state's reversionary right to the water. It would only prevent the licensed user from later asserting a paramount right against the prescriptor.

\section{A. Prescriptive Rights Against Riparians Should Not Be Abolished}

The Governor's Cominission marshals several arguments in favor of abolishing prescriptive rights in water. Closer examination, however, demonstrates that none of the Commission's arguments apply to prescriptive rights asserted against riparians.

The Commission contends that prescriptive rights impair the Board's mandated decisionmaking role. ${ }^{162}$ But the Board's only jurisdiction over riparian water is the power to attack the riparian's right collaterally in an action to prevent waste. ${ }^{163}$ Water that is needed for reasonable and beneficial riparian use is not subject to statutory appropriation. ${ }^{164}$ Thus, allowing a prescriptive right to prevail against a riparian will not affect the Board's hmited authority over riparian rights.

Nor is the Commission's concern for uncertainty ${ }^{165}$ ground enough for abolishing prescriptive rights against riparians. Since riparian uses need not be registered with the Board, ${ }^{166}$ the scope of riparian rights is only certain where the Board has determined rights in an entire streain system. ${ }^{167}$ Abrogating prescriptive rights and resurrecting

161. An adverse user probably could not establish a prescriptive right against a riparian owner except in rare cases. To be adverse, the prescriptive diversion would have to interfere with the riparian's reasonable and beneficial use of the water. See text accompanying note 70 supra. Thus, im order to prevail, the prescriptive claimant would have to show that the riparian could have beneficially used the water if available. This may be difficult to establish, because the riparian would naturally claim that if he could have used the water reasonably and beneficially, he would have objected to the diversion before the five-year prescriptive period had run. The prescriptive claimant might, however, be able to negate that claim by demonstrating, for example, that the riparian obtained and used water from other sources during the prescriptive period.

162. GOVERNOR'S COMMISSION, supra note 23, at 32.

163. See CAL. WATER CODE $\$ 275$ (Deering 1977) (“[B]oard shall take all appropriate proceedings or actions before executive, legislative, or judicial agencies to prevent waste, unreasonable use, unreasonable method of use, or unreasonable method of diversion of water in this state"); People v. Forni, 54 Cal. App. 3d 743, 747, 126 Cal. Rptr. 851, 853 (Ist Dist. 1976).

164. See, e.g., Stevinson Water Dist. v. Roduner, 36 Cal. 2d 264, 269-70, 223 P.2d 209, 212 (1950); City of Pasadena v. City of Alhambra, 33 Cal. 2d 908, 925-26, 207 P.2d 17, 28 (1949).

165. GOVERNOR's COMMISSION, supra note 23, at 17-18.

166. CAL. WATER CODE $\$ \S 5100-5108$ (Deering 1977) requires that most persons using water other than under a Board permit or license file a statement of their water diversion and use. However, there is no sanction for noncompliance.

167. See In re Waters of Long Valley Creek Stream Sys., 25 Cal. 3d 339, 599 P.2d 656, 156 Cal. Rptr. 350 (1979); CAL. WATER CODE $\$ \S 2500-2866$ (Deering 1977). 
lost riparian rights will not alleviate this uncertainty. ${ }^{168}$

The Commission also argues that adverse use does not give fair notice to the owner of the water right. ${ }^{169}$ A decreased water supply may result as easily froin hydrologic changes or lawful upstream uses as from adverse use. ${ }^{170}$ However, the prescriptive claimant already bears the burden of proving that the rightful owner had notice of the adverse use. ${ }^{171}$ Although the claimant need not show actual notice, ${ }^{172}$ he inust at least show that a reasonably diligent person would have inquired why the flow had diminished ${ }^{173}$ and that such an inquiry would have revealed the adverse use. ${ }^{174}$ The potential burden on the riparian owner is not great enough to warrant abolishing prescriptive rights.

Moreover, the Commission's proposal ignores the policy allowing adverse use to ripen into a vested right in land-that land should be used and not lie idle. ${ }^{175}$ This policy is even inore compelling with respect to scarce water resources. Since riparian rights are paramount, prescription may be the only way for a water user to protect his supply. ${ }^{176}$ Rewarding the diligent, reasonable and beneficial adverse user ${ }^{177}$ with a vested right over the nondiligent riparian seems only equitable. ${ }^{178}$

\section{B. The State Should Recognize a Limited Prescriptive Right in Water Subject to Statutory Appropriation}

"Surplus" or public water, once allocated by permit, is no longer ing).

168. 26 Cal. $3 d$ at 321,605 P.2d at 872, 162 Cal. Rptr. at 43 (Clark, J., concurring and dissent-

169. GOVERNOR's COMMISSION, supra note 23, at 32.

170. Id.

171. See note 116 and accompanying text supra.

172. Where the rightful owner has actual knowledge of an adverse claim and makes no objection, the use is adverse. See 2 Hutchins-1974, supra note 46, at 355.

173. See 1 Rogers \& NicHoLs, supra note $9, \S 238$.

174. See Jones v. Harmon, 175 Cal. App. 2d 869, 879, I Cal. Rptr. 192, 199 (2d Dist. 1959) (it is a question of fact whether circumstances charge owner with constructive notice of adverse use).

175. Teisen, Adverse Possession, 1917 A.B.A.J. 126, 127. See also Maritz v. Buglewicz, 187 Neb. 819, 821, 194 N.W.2d 215, 216 (1972) (public policy favors full utilization of land); accord, Drye v. Eagle Rock Ranch, Inc., 364 S.W.2d 196, 212 (Texas 1963).

176. While future riparian rights may be accorded a lower priority than appropriative rights in a statutory adjudication proceeding, In re Waters of Long Valley Creek Stream Sys., 25 Cal. 3d 339, 358-59, 599 P.2d 656, 668-69, 158 Cal. Rptr. 350, 362-63 (1979), prescription may still be the only means by which an appropriator could secure his water supply agamst a riparian's present right.

177. In order for a prescriptive water right to attach, the adverse user must show that the water is actually being used for a reasonable and beneficial use. Lee v. Pacific Gas \& Elec. Co., 7 Cal. 2d 114, 120, 59 P.2d 1005, 1008 (1936); 1 Rogers \& Nichols, supra note 9, § 236.

178. See 1 Rogers \& Nichols, supra note $9, \S 227$, at 327. 
subject to Board appropriation. ${ }^{179}$ If Board-allocated water is not used for three years, however, it reverts to the state. ${ }^{180}$ Once the reversion occurs, the water would again becoine "water subject to appropriation," and under Shirokow, the state could seek to enjoin any unpermitted use under section $1052 .^{181}$ Because the reversion would occur before the five-year prescriptive period could expire, ${ }^{182}$ an unauthorized appropriator who diverts water allocated to another could never obtain an absolute water right, good against the world, by prescription. ${ }^{183}$ Even though the permit holder might lose the right to objecteither because of the statutory reversion to the state ${ }^{184}$ or because of the

179. See CAL. Water Code $\S 1202$ (Deering 1977); 1 Rogers \& Nichols, supra note 9, $\S 227$.

180. Cal. Water CODE $\S 1241$ (Deering 1977). For a general discussion of the effect of forfeiture statutes, see 2 Hutchins-1974, supra note 46, at 292, 313-15; Craig, supra note 58, at 236-38.

181. See text accompanying note 96 supra.

182. Water diverted under a pre-1914 appropriative right is also not subject to appropriation. City of Pasadena v. City of Alhambra, 33 Cal. 2d 908, 925-26, 207 P.2d 17, 28 (1949). The threeyear statutory forfeiture under CAL. WATER CODE $\$ 1241$ (Deering 1977), however, does not apply to pre-1914 appropriative rights. Instead, these rights are lost only through abandonment or nonuse for five years. Smith v. Hawkins, 110 Cal. 122, 127-28, 42 P. 453, 455 (1895), 120 Cal. 86, 88,52 P. 139, 140 (1898). Thus, the forfeiture period could correspond with the five-year prescriptive period. Nevertheless, an absolute prescriptive right should not be permitted to attach to water clained under a pre-1914 appropriation. This Note argues that the court should continue to recognize absolute prescriptive rights as against riparians because if the preseriptive rights doctrine is abandoned, the result would be to resurrect the riparian right. See text accompanying note 168 supra. This would occur because a riparian right cannot be lost through nonuse. Hutchins, supra note 21, at 284. In contrast, a pre-1914 appropriative right that had been dormant for five years would not be resurrected; it would simply be lost and the water would again be subject to statutory appropriation by the Board. See CAL. WATER CODE $§ 1202$ (Deering 1977). Recognizmg an absolute prescriptive right would thus subvert the policy of permitting the Board to manage the state's water resources to the fullest extent possible. See text accompanying notes 99-103 and 137 supra. Instead, a limited prescriptive right as discussed in text accompanying notes 179 82 supra and 183-96 infra should be recognized.

183. A true prescriptive right vests the adverse user with a perfect, unassailable water right, good against the world. See note 57 and accompanying text supra.

If the appropriator had a permit but adversely diverted water rightfully belonging to a permit holder with a higher priority, the effect would be to extinguish the senior rights. See HuTchins, supra note 21, at 323. However, the appropriator still could not perfect an absolute, unassailable right to the water as against the state. All water rights permits contain standard terms giving the Board continumg jurisdiction. See 23 CAL. Admin. Code $\$ 761$ (a) (Jan. 28, 1977). Cf. CAL. WATER CODE $\$ 1394$ (Deering 1977) (Board may reserve jurisdiction to annend terms and conditions in a permit but such jurisdiction may not be exercised after issuance of a license). The Board may institute revocation proceedings if the terms and conditions of the permit are violated. CAL. WATER CODE $\S 1410$ (Deermg 1977); 23 CAL. Admin. CODE $\$ 790$ (Mar. 10, 1960).

184. At least one other jurisdiction has held that no statutory reversion can occur where an appropriator ceases use of water due to another's adverse use. Wellsville East Field Irr. Co. v. Lindsay Land \& Livestock Co., 104 Utah 448, 460, 137 P.2d 634, 640 (1943). California would probably not adopt this rule, if it meant a preseriptive right could be perfected against the state, for it would undermine the primciple, strongly endorsed by the 1978 Governor's Coinmission, that 
bar of the statute of limitations ${ }^{185}$ - the state would still have the right to enjoin the unauthorized diversion.

The court, however, has recognized in recent cases that private water rights litigation "determin[es] only the relative rights of tlie parties before the court."186 An unauthorized appropriator should therefore be able to perfect a prescriptive right against an authorized private appropriator without prejudicing the state's power to enjoin the trespass under section 1052 or to compel a reversion. The state's right to the water would remam paramount. However, a private party could not maintam an action to enjom the adverse use after the five-year statute of limitations had passed. ${ }^{187}$

Since the state's right would remain paramount under this theory of limited prescriptive rights in surplus water, a permit would still be required to vest the right in the user. The Board would still determine, either through the statutory appropriation process or through its authority to institute a section 1052 injunction action, wliether the adverse user is puttimg the water to reasonable and beneficial use in the public interest. Any uncertainty as to the scope of the prescriptive right would necessarily be eliminated by judgment im the hitigation. ${ }^{188}$ Therefore, the Commission's arguments for wholesale abolition of prescriptive rights do not apply to this theory of limited prescriptive rights in water subject to statutory appropriation.

The Shirokow dissenters claimed that recognizing limited prescrip-

the Board should determine who may use public water. Governor's Commission, supra note 23, at 27-30.

Moreover, exceptions to the California forfeiture rule are limited. Only three are set out in statute, CAL. WATER CODE $\S \S 1011,1241.5-6$ (Deering 1977), while the only judicial exception to the forfeiture rule has been where the nonuse resulted from circumstances beyond the owner's control. See Bloss v. Rahilly, 16 Cal. 2d 70, 78, 104 P.2d 1049, 1053 (1949) (appropriative right not lost by fact that quantity of water flowing into stream was-reduced by circumstances beyond the owner's control); Huffner v. Sawday, 153 Cal. 86, 92, 94 P. 424, 426 (1908) (natural shortage did not cause forfeiture of appropriative right under judicially adopted five-year forfeiture period). Since the statutory appropriator must defend his own right agamst encroachment by others, see APPROPRIATION OF WATER, supra note 20, at 4, he can hardly claim another's adverse use as a circumstance beyond his control.

185. See note 58 supra.

186. Environmental Defense Fund v. East Bay Mun. Util. Dist., 26 Cal. 3d 183, 199, 605 P.2d 1, 9, 161 Cal. Rptr. 466, 474 (1980); In re Waters of Long Valley Creek Stream Sys., 25 Cal. 3d 339, 347, 599 P.2d 656, 660, 158 Cal. Rptr. 350, 354 (1979). In a footnote, the Shirokow court equates prescription with a simple statute of limitations bar. $26 \mathrm{Cal} .3 \mathrm{~d}$ at $311 \mathrm{n} .14,605$ P.2d at 866 n.14, 162 Cal. Rptr. at 37 n.14.

187. See Hudson v. West, 47 Cal. 2d 823, 827, 306 P.2d 807, 808 (1957) (court declined to consider permit requirement argument raised by Board as amicus in prescriptive rights case, pointing out that state's interests were not prejudiced).

188. The prescriptive right cannot exceed the quantity of water actually diverted and put to reasonable beneflcial use. The judgment in a prescriptive rights action declares the right to make the diversion of water in the quantity taken during the prescriptive period. See Hutchins, supra note 21 , at 338 . 
tive rights in private litigation would have no practical effect. ${ }^{189}$ To avoid unlawful discrimination, the Board would have to enjoin all nonpermitted uses. Faced with a certain injunction, adverse users would not in practice seek to establish their right through suit.

This argument has two flaws. First, a prescriptive rights claim need not only be asserted affirmatively; it is just as likely to appear as a defense. ${ }^{190}$ Second, a section 1052 injunction is not inevitable. ${ }^{191}$ The Board's power to bring an action under section 1052 is discretionary and apparently is rarely exercised. ${ }^{192}$ A private party seeking to compel the Board to bring an action via a writ of mandate would prevail only if he slowed an abuse of discretion. ${ }^{193}$ Before seeking an injunction, the Board will probably act as it did in Shirokow and give the unauthorized appropriator an opportunity to protect his water use by applying for a permit. ${ }^{194}$

Recognizing limited prescriptive rights in water subject to appropriation would mean that the court need not overrule those cases that recognize prescriptive rights based on post-1914 use without inentioning the need for a permit. ${ }^{195}$ More importantly, it would allay Justice Clark's concern that the abolition of prescriptive rights will subject public utilities and municipalities, whose water rights rest on previously adjudicated prescriptive rights, to claims of inverse condemna-

189. 26 Cal. $3 d$ at 318 n.3, 605 P.2d at 871 n.3, 162 Cal. Rptr. at 41 n.3 (Clark, J., concurring and dissenting).

190. See, e.g., Hudson v. West, 47 Cal. 2d 823, 826, 306 P.2d 807, 808 (1957); Moore v. California Or. Power Co., 22 Cal. 2d 725, 735, 140 P.2d 798, 804 (1943).

191. See note 142 and accompanying text supra.

192. CAL. WATER CODE $\S 1052$ (Deering 1977) provides the "board may institute" an injunction action (emphasis added). Besides Shirokow, only one other $\$ 1052$ case has been reported. State v. Hansen, 189 Cal. App. 2d 604, 11 Cal. Rptr. 335 (4th Dist. 1961). Even Hansen technically was not a proper case in which to employ $\& 1052$, because the water involved-a spring located on state land-was not water subject to appropriation. See id. at 610,11 Cal. Rptr. at 339 .

193. See Temescal Water Co. v. Department of Public Works, 44 Cal. 2d 90, 106, 280 P.2d 1, 11 (1955) (proper remedy for review of Board's discretionary act is writ of mandate purspant to Cal. Civ. Proc. Code $\S 1094.5$ ). Cf. Cal. Water Code $\$ \S 1360,1412,1615$ (Deering 1977) (authorizing writ of mandate to inquire into validity of Board action). See generally' 2 HuTchins1974, supra note 46, at 249-51. A court cannot order an act within an agency's discretion or substitute its discretion for that of an administrative state agency. CAL. Clv. Proc. Code $\S 1094.5(b)$, (e) (Deering 1979 Supp.). See generally 2 CAL. JUR. 3D, Administrative Law $\S 310$, 337 (1973).

194. See text accompanying notes 10-11 supra.

195. See, e.g., Locke v. Yorba Irr. Co., 35 Cal. 2d 205, 211 , 217 P.2d 425, 429 (1950); Moore v. California Or. Power Co., 22 Cal. 2d 725, 735, 140 P.2d 798, 804 (1943); Seneca Consol. Gold Mines Co. v. Great W. Power Co., 309 Cal. 206, 287 P. 93 (1930); Orange County Water Dist. v. City of Riverside, 173 Cal. App. 2d 137, 197-98, 343 P.2d 450, 484-85 (4th Dist. 1959); Lindsay v. King, 138 Cal. App. 2d 333, 340-41, 292 P.2d 23, 28 (1st Dist. 1956); Big Rock Mtn. Water Co. v. Valyermo Ranch Co., 78 Cal. App. 266, 271-74, 248 P. 264, 266-67 (Ist Dist. 1926). See also KLETZING, supra note 73 , at 375 (pointing out that most post-1914 prescriptive rights cases did not mention the necessity of a permit). 
tion. ${ }^{196}$ Yet the policies behind the Governor's Commission report would not be slighted. If California recognizes only the limited prescriptive right recommended in this Note, the state would retain paramount title and the Board's jurisdiction over the state's water resources would remain unimpaired.

\section{CONCLUSION}

Although Shirokow's result is sound, the decision did not confront the issue of whetler water waste would result if the state were granted an injunction under California Water Code section 1052. Given California's constitutional water conservation policy, proof of waste must be recognized as an affirmative defense to a complaint filed under section 1052. Although Shirokow eliminates the possibility that an adverse user can perfect a prescriptive water right against the state, it leaves open the possibility that sucli riglts may be perfected between private parties. This Note argues that it is consistent with state water policy to recognize prescriptive rights in water that is not subject to statutory appropriation because of paramount riparian rights. Similarly, a hinited prescriptive right, one that does not interfere with the state's regulatory scheme, should be recognized in water subject to statutory appropriation.

Teressa $K$. Lippert*

196. See text accompanying note 124 supra.

* B.A. 1971, University of New Mexico; third-year student, Boalt Hall School of Law, University of California, Berkeley. 